\title{
EPIDEMIOLOGICAL, CLINICAL, MOLECULAR FEATURES AND EARLY DETECTION STRATEGY OF MOST FREQUENT HEREDITARY CANCERS IN LATVIA
}

\author{
Jānis Gardovskis*, Ilze Štrumfa*, Edvīns Miklaševičs*, Arvīds Irmejs*, \\ Genādijs Trofimovičs*, Egils Vjaters*, Viktors Borošenko*, Inga Melbārde-Gorkuša*, \\ Andris Gardovskis*, Andrejs Vanags*, Andris Ābele*, Signe Subatniece*, \\ Marianna Bitina* ${ }^{*}$ Liāna Švampāne**, Jekaterina Žestkova*, Dace Bērziṇa*, \\ Karina Aksenoka*, Viesturs Boka**, Aldis Pukiitis" ${ }^{\star * *}$, Aiga Stāka***, \\ and Laima Tihomirova**

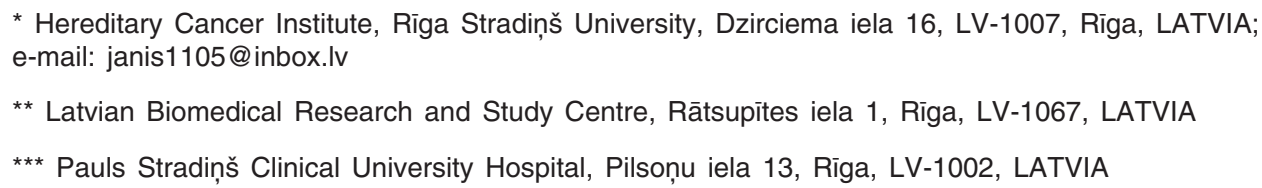

Contributed by Jānis Gardovskis

\begin{abstract}
The aim of the study was to determine epidemiological, clinical and molecular features of hereditary breast-ovarian, colorectal, endometrial, prostate and pancreatic cancer in Latvia. The study was performed from 2006 to 2009. Family cancer histories and DNA samples from 5,040 cancer cases were collected, and more than 6,000 molecular tests were performed including multiplex $P C R$, direct sequencing, denaturing high performance liquid chromatography and others. For the first time, a BRCA2 gene mutation positive hereditary breast cancer family was identified. The necessity of 2 BRCA1 gene founder mutations testing, irrespective of family cancer history for breast and ovarian cancer patients, was confirmed on a large number of positive cases. Regarding hereditary ovarian cancer, every ninth case affected with this malignancy was associated with the BRCA1 gene mutation. For the first time, positive familial adenomatous polyposis cases positive for APC gene mutation were reported and data on the clinical frequency of hereditary endometrial and prostate cancer were provided. In pancreatic cancer patients there was a 3.5\% frequency of BRCA1 gene founder mutations.
\end{abstract}

Key words: breast, ovarian, colorectal, endometrial, prostate, pancreatic hereditary cancer.

\section{INTRODUCTION}

General. Hereditary cancer accounts for $15-20 \%$ of all cancers, it is potentially predictable and preventable and still is the $2^{\text {nd }}$ most common cause of death in developed countries. It is not expected that conventional therapeutic methods like surgery, chemotherapy or radiotherapy can achieve any further improvement in survival in the nearest 5-10 years. Therefore, identification of groups at increased cancer risk with appropriate screening programmes and preventive measures is one of the most perspective fields of oncology.

The most common hereditary cancers known presently are breast, ovarian, colorectal, endometrial, prostate and pancreatic. They account for the largest proportion of cases and have the largest clinical significance.
Significant ethnic and geographical variations of clinical and molecular features exist for hereditary cancers in different populations. Knowledge of clinical and molecular features is crucial to identify successfully the risk groups of hereditary cancers in a particular geographic area. There are several populations, including neighbouring Poland and Finland, where different diagnostic criteria and specific molecular strategies need to be applied (Bratt, 2000; Hughes et al., 2005). Therefore, the aim of the research was to study the clinical and molecular features of the most frequent hereditary cancer syndromes in Latvia in order to optimise early diagnosis and promote prevention measures of hereditary cancer.

The paper covers several mutually related studies, and each section (introduction, materials and methods, results, discussion, conclusions) of this paper will start with short gen- 
eral data followed by five separate blocks (breast and ovarian, colorectal, endometrial, prostate and pancreatic cancer studies).

Breast and ovarian cancer. Breast cancer is the most frequent cancer among women in Latvia (Globocan, 2002). There are approximately 1,000 new breast cancer cases diagnosed every year in Latvia (the most recent data indicating that there were 1,056 new cases detected in the year 2007). According to the of the Cancer Registry of Latvia (Anonīms, 2007), $61.7 \%$ of patients were diagnosed with stage I or II disease in 2007. According to CRL data, there were 306 new ovarian cancer patients diagnosed in 2007. Only $22.0 \%$ of patients were diagnosed with stage I or II disease. The majority of ovarian cancers $(78.0 \%)$ were diagnosed with stage III or IV disease. Therefore, it is very important to identify the group at risk from breast and ovarian cancers in order to employ prevention or early detection of cancer in patients and their family members.

The majority of breast and ovarian cancers are considered sporadic. Approximately 15-20\% of all breast and ovarian cancers are hereditary (Ford et al., 1998; Vasen et al., 2001; Jacobi et al., 2003). The incidence of hereditary breast and ovarian cancer may vary considerably among different populations and ethnic groups. In the last ten years, mutations in both BRCA1 and BRCA2 genes have been shown to be responsible for the development of hereditary breast and ovarian cancer. The aim of the study was to determine clinical and molecular and pathological features of hereditary breast and ovarian cancer in Latvia.

Colorectal cancer. In 2007, there were 1099 new colorectal cancer cases diagnosed in Latvia. Of all newly diagnosed cancers only $17.4 \%$ were detected in stage I, and $22.9 \%$ in stage II and, accordingly, one would expect about 90 to 130 familial cases in Latvia annually. From this estimate, 20-60 of them are most likely to be associated with a hereditary condition - either hereditary nonpolyposis colorectal cancer (HNPCC) or familial adenomatous polyposis (FAP). Detection and appropriate management of patients affected with disease or those with an increased risk it would provide a considerable improvement in oncology care in Latvia.

There is continuing interest in identifying DNA variants associated with moderately increased risk of cancer. Several studies have suggested an increased risk of cancer in individuals who carry a mutation in the CHEK2 gene, one of the genes in the DNA damage signaling pathway. Originally, a single founder allele in $C H E K 2,1100 \mathrm{delC}$, was reported to be a low penetrance breast cancer susceptibility allele in several studies, and in many ethnic groups (Jarvinen, 1992; Bülow et al., 1996; Gorski et al., 2000; Chapelle, 2004). Then, a positive association was found between CHEK2 variants and prostate cancer in the USA, Finland and Poland (Bisgaard et al, 2004; Aretz et al., 2007; Anonīms, 2007). Recently, it was reported that individuals with a single common founder allele in Poland (the I157T missense variant) have increased risk of cancer develop- ment in many organs including the breast, prostate, thyroid, kidney and colon (Kilpivaara et al., 2003). The NOD2 gene is associated with susceptibility to inflammatory bowel disease, in particular, with Crohn's disease (Kurzawski et al, 2004). It was reported that a single truncating mutation in NOD2, 3020insC, may confer increased risk of late onset colorectal cancer (Ogura et al., 2001) and then that a NOD2 mutation may be associated with increased susceptibility to lung, ovarian, early-onset laryngeal cancer and early onset breast cancer (Lichtenstein et al., 2000). It has not been established whether CHEK2 and NOD2 variants are present in Latvia and whether inherited variation in these genes influences cancer risk in this population.

The aim of the study was to investigate the clinical and molecular features of hereditary colorectal cancer syndromes in Latvia in order to offer and provide predictive genetic testing of the affected families.

Endometrial cancer. Endometrial cancer (EC) is among the three most common cancers in females in Latvia. There are approximately 390 new cases diagnosed every year in Latvia (Cancer Registry of Latvia). The annual incidence has been estimated at 31.0-31.3 and 9.9-11.9 deaths per 100,000 women.

The clinical features of hereditary endometrial cancer were examined in relation to the heritability of endometrial adenocarcinoma. We focussed on identifying the impact of the frequency and patient age at the onset of cancer in families having first- and second-degree relatives on developing heritable tendencies.

Prostate cancer. Prostate cancer is the second most commonly diagnosed malignancy in men in Latvia after lung cancer. It is also one of the major causes of death among men in Latvia. A significant factor in prostate cancerogenesis is genetic (Lichtenstein et al., 2000). The failure to identify highly penetrant genes in hereditary prostate cancer may result from the fact that multiple genes with a small to moderate effect are involved (Hughes et al, 2005). To-date, the well-known and widely researched genes that determine this predisposition are: BRCA1, BRCA2, ELAC2, RNASEL, MSR1, NBS1 and CHEK2 (Bratt, 2000; Cybulski et al., 2004a,b; Rennert et al., 2005). The aim of the study was to identify genes involved in the predisposition to hereditary prostate cancer; to evaluate the epidemiological features and molecular basis of hereditary prostate cancer in the population of Latvia, as well as to consider the clinical implications.

Pancreatic cancer. In Latvia 367 cases were registered in 2005 (199 males and 168 females). In 1980, there were only 253 cases (127 males and 126 females), which indicates an increasing disease incidence in Latvia. However, these numbers are much higher than in other European countries, which can be explained by hyperdiagnostics, since in Latvia there is still a low histological verification of pancreatic cancers (on average 17-18\%). The number of radical operations registered in 2005 was $13(3.5 \%)$. The 
mortality rate in Latvia in 2005 was 356 cases, which shows that the incidence is almost proportional to mortality. In 2005, pancreatic ranked $4^{\text {th }}$ in Latvia in mortality rate among males and $7^{\text {th }}$ among females. As early diagnostic and successful treatment is still not available, it is necessary to develop control criteria to identify people at high risk, who could be monitored by means of a screening protocol for the more earlier detection of pancreatic cancer.

We determined the prevalence of inherited pancreatic cancer and the prevalence of inherited gene mutation in pancreatic cancer patients in Latvia. Mutations such as BRCAl prevailing mutations, the ARLTS1 gene prevailing mutations, the CDNK2A and STK11 gene mutations were identified in cancer patients and compared to a control group.

\section{MATERIALS AND METHODS}

The study was performed from 2006 to 2009. Family cancer histories and DNA samples were collected from 5,040 cancer cases. In total, more than 6,000 molecular tests were performed, including multiplex PCR, direct sequencing, denaturing high performance liquid chromatography (DHPLC) and others.

Both clinical and molecular features were examined. Family cancer history and clinical data was collected using a questionnaire in which the following questions were asked: Have your relatives (father, mother, grandparents, siblings, children, grandchildren, aunts, uncles) had any tumour? What was the localisation of the tumour? At what age was the tumour was detected? Analysis of family cancer history was performed according to international diagnostic criteria of hereditary cancer syndromes. The study design was approved by the Central Committee of Medical Ethics.

Breast and ovarian cancer. In this prospective study, cancer family histories and blood samples were collected from 2,525 consecutive hospital based patients in the largest oncology hospitals of Latvia. There were 2,008 breast and 517 ovarian cancer cases.

All patients completed family cancer history questionnaire. Family cancer histories were analysed according to diagnostic criteria for hereditary breast and ovarian cancer, summarised in Table 1.

In all individuals, for whom a blood sample was obtainable, $10 \mathrm{ml}$ of venous blood was taken and molecular testing for founder mutations in the BRCAl gene $(300 \mathrm{~T} / \mathrm{G}, 4153 \mathrm{delA}$ and 5382insC) was performed, after obtaining written informed consent from each patient. DNA from the BRCAl founder mutation negative patients was screened by direct sequencing of entire coding sequences of the BRCAl and $B R C A 2$ genes and flanking intronic sequences of each exon on an ABI PRISM 310 genetic analyser.

Colorectal cancer. Family cancer history, clinical data and DNA samples were collected from 1,053 colorectal cancer
Table 1

CLINICAL DIAGNOSTIC CRITERIA FOR HEREDITARY BREAST AND OVARIAN CANCER

\begin{tabular}{|l|l|l|}
\hline $\begin{array}{l}\text { HBC suspected (susp.) } \\
\text { HBOC susp.1 }\end{array}$ & $\begin{array}{l}\text { HBC susp.2 } \\
\text { HBOC susp2. }\end{array}$ & $\begin{array}{l}\text { HBC } \\
\text { HBOC }\end{array}$ \\
\hline $\begin{array}{l}\text { One-case families - } \\
\text { at least one of the fol- } \\
\text { lowing criteria has to } \\
\text { be met: }\end{array}$ & $\begin{array}{l}\text { Two-case families - } \\
\text { one of the following } \\
\text { criteria has to be met: }\end{array}$ & Three-case families \\
\hline $\begin{array}{l}\text { - breast cancer diag- } \\
\text { nosed under age 40 } \\
\text { - medullary or atypical } \\
\text { medullary breast can- } \\
\text { cer } \\
\text { - male breast cancer } \\
\text { - breast and ovarian } \\
\text { cancer in the same in- } \\
\text { dividual at any age } \\
\text { - bilateral breast can- } \\
\text { cer, one of them diag- } \\
\text { nosed under age 50 }\end{array}$ & $\begin{array}{l}\text { - two breast or two } \\
\text { ovarian cancers among } \\
\text { (orstecond through } \\
\text { male) at any age } \\
\text { - one breast cancer di- } \\
\text { agnosed under age 50 } \\
\text { and one ovarian cancer } \\
\text { diagnosed at any age at and } \\
\text { any age first degree } \\
\text { relatives (or second } \\
\text { through male) relatives }\end{array}$ & $\begin{array}{l}\text { - at least three breast } \\
\text { or ovarian cancers pa- } \\
\text { tients on the same side } \\
\text { of family diagnosed at } \\
\text { any age one of those } \\
\text { through male) relative } \\
\text { to other two }\end{array}$ \\
\hline
\end{tabular}

$\mathrm{HBC}$, hereditary breast cancer; HBOC, hereditary breast and ovarian cancer; HBOC susp., suspected HBOC

cases. Family cancer history was analysed according to the following clinical-diagnostic criteria.

Hereditary nonpolyposis colorectal cancer diagnostic criteria: 1) at least three relatives with cancer (colorectal, endometrial, intestinal, pyelonal or ureteral), at least one is a $1^{\text {st }}$ degree relative to the other two; 2) cancer in two generations at least; 3 ) diagnosis before age 50 in at least one case; 4) FAP excluded.

Suspected diagnostic criteria of HNPCC: two generations with HNPCC (colorectal, intestinal, pyeloureteral, endometrial, ovarian) affected; at least one diagnosed under age of 50 years. FAP diagnostic criteria: more than 100 polyps in colorectal area.

Additionally, six polyposis (> 50 polyps in colorectal area) patients, along with three of their relatives, were included in this study. Two of these patients were selected from the colorectal cancer database (from a total of 2,552) and four patients not affected with colorectal cancer (CRC) were referred from the endoscopic facility of Pauls Stradin̄s Clinical University Hospital.

In cases matching HNPCC criteria or with suspected HNPCC criteria, testing of the MLH1, MSH2 genes was performed. Screening for germline mutations was performed by DHPLC followed by sequencing of polymorphic regions (Kurzawski et al., 2002).

In cases with more than 50 polyps screening for point mutations in the APC gene was performed on genomic DNA using the protein truncation test (PTT) for mutations in exon 15 , and denaturing high performance liquid chromatography (DHPLC) for mutations in exons 1-14 and the first 400 
base pairs of exon 15 (Bisgaard et al., 2004; Aretz et al., 2007).

362 consecutive colorectal cancer patient samples and 963 control blood samples were tested for the presence of mutations in moderate penetrance cancer predisposing genes (CHEK2 I157T, NOD2 3020insC, p16) by PCR. In addition, all patients underwent genetic counselling.

Endometrial cancer. From January 2006 to January 2009, 672 family cancer histories were compiled from consecutive hospitalised endometrial cancer patients in the Latvian Oncology Center of Rīga Eastern Clinical University Hospital. These family histories of cancer were analysed according to the diagnostic criteria of hereditary endometrial cancer (HEC). Hereditary endometrial cancer three first-degree relatives with endometrial cancer, one of the cancers diagnosed before age of 50 years; suspicion of hereditary endometrial cancer (HEC susp.) - two first-degree relatives with endometrial cancer, one of the cancers diagnosed before age of 50 years; familial endometrial cancer (FEC) three first-degree relatives with endometrial cancer, at any age; suspicion of familial endometrial cancer (FEC susp.) - two first- or second-degree relatives with endometrial cancer, at any age. If there were no malignancies among blood relatives of the proband, the family was classified as "negative". If there was one malignancy among blood relatives, but the family did not match the diagnostic criteria of any hereditary endometrial cancer syndrome, the family was classified as "other".

Prostate cancer. 676 families with prostate cancer were selected for our study; they were collected between January 2006 and January 2009. Data were compiled on clinical characteristics; additionally blood samples were collected for DNA tests. Prostate cancer family histories were analysed separately depending on positive or negative family cancer history data and according to definitive and suspect hereditary prostate cancer clinical diagnostic criteria as follows: (1) definitive hereditary prostate cancer was characterised, if at least one of the following criteria applied: (a) at least three affected blood relatives at any age; or (b) two affected blood relatives at age $\leq 55$ years; and (2) suspect hereditary prostate cancer was characterised, if at least one of the following criteria applied: (c) single case of prostate cancer diagnosed at age $\leq 55$ years; or (d) family with two prostate cancer cases at any age. DNA testing was performed for first 280 prostate cancer patients and 173 control cases in the NBS1 gene $657 \mathrm{del} 5$ mutation and for 59 cases in the BRCAl gene mutations:, 300T/G, 4153delA and 5382insC.

Pancreatic cancer. In the first stage, patients with adenocarcinoma of pancreas were selected and 114 patients with a confirmed diagnosis of pancreatic cancer were included into the study.

In the second stage, these patients compiled a detailed family history of cancer. Patients with a familial risk were those who have at least two first-degree kinship relatives with pancreatic cancer.

In the third stage, blood samples were taken from the pancreatic cancer patients and sent to the Latvian Biomedical Research and Study Centre for analysis of inherited gene mutations.

Blood of 114 patients was tested for the BRCAl gene prevailing mutations in Latvia (5382insC, 4154delA, 300T $>\mathrm{G}$ and $185 \mathrm{delAG})$. A control group (640 patients) was analysed for 5382insC and 4154delA mutations; 90 patients for the $C D K N 2 A$ gene coding sequence (coding p16 protein); 39 patients were tested for the $C D K N 2 A$ gene $1 \beta$ alternative exone, which codes the p14 ARF sequence; 90 patients for the STK11 gene 3rd exone mutations; and 90 patients for the ARLTS1 gene prevailing mutations (Pro131Leu, Cys148Arg and Trp149Stop). In the control group 256 DNA samples were analysed. The mean age of participants was 57 years.

In the fourth stage, questionnaires on family history of inherited pancreatic cancer patients were compiled using Liverpool University questionnaires, and the collected blood samples were sent to the Liverpool University for determination of BRCA2 mutations. The BRCA2 gene was analysed, using all 28 exons (except the $1^{\text {st }}$ exon, which is a nontranslating area) for DNA fragment amplification and analysis by 38 direct and reverse oligonucleotide primer pairs.

\section{RESULTS}

Breast and ovarian cancer. Among 2,008 breast cancer family histories analysed, $17(0.8 \%)$ cases fulfilled the criteria of hereditary breast cancer (HBC). Hereditary breast and ovarian cancer (HBOC) was diagnosed in 15/2,008 $(0.7 \%)$ cases. In 290/2,008 (14\%) cases a suspicion of hereditary breast cancer (HBC susp.) was detected. A further $22 / 2,008(1.0 \%)$ cases were designated as being suspicious for hereditary breast and ovarian cancer (HBOC susp.).

Among 517 analysed histories with family ovarian cancer, $11(2.0 \%)$ cases fulfilled the criteria of hereditary breast and ovarian cancer (HBOC) and 22/517 (4.0\%) cases were designated as being suspicious for hereditary breast and ovarian cancer (HBOC susp.). Only 6/517 (1.0\%) cases of hereditary ovarian cancer (HOC) were observed. Suspicion of hereditary ovarian cancer was diagnosed in 22/517 $(4.0 \%)$ cases.

DNA testing of the BRCAl gene $(300 \mathrm{~T} / \mathrm{G}, 4153 \mathrm{delA}$, 5382insC) was performed for all breast $(2,008)$ and $(517)$ ovarian cancer patients. In the breast cancer patient group, $65 / 2,008(3.0 \%)$ with mutations were detected. Sixteen mutations in the BRCAl gene were identified in $4153 \mathrm{delA}$ and 48 mutations in 5382insC and 1 in 300T/G.

In the group of patients with ovarian cancer, mutations in the BRCAl gene were identified in $57 / 517(11 \%)$ cases of 
Table 2

MUTATIONS IN THE BREAST CANCER CLINICAL GROUP

\begin{tabular}{lcccc}
\hline $\begin{array}{c}\text { Diagnostic } \\
\text { criteria }\end{array}$ & $\begin{array}{c}\text { All cases } \\
\mathrm{n}\end{array}$ & $\begin{array}{c}\text { Number of } \\
\text { BRCA1 mutation }\end{array}$ & $\begin{array}{c}\text { Frequency of } \\
\text { mutation }\end{array}$ \\
\hline HBC & 17 & 1 & 5.9 \\
HBOC & 15 & 6 & 40.0 \\
HBC susp. & 290 & 23 & 7.9 \\
HBOC susp. & 22 & 5 & 22.7 \\
Others & 1664 & 30 & 1.8 \\
Total & 2008 & 65 & 3.0 \\
\hline
\end{tabular}

For abbreviations see Table 1.

Table 3

MUTATIONS IN OVARIAN CANCER CLINICAL GROUP

\begin{tabular}{l|c|c|c}
\hline Diagnostic criteria & $\begin{array}{c}\text { All cases } \\
\mathrm{n}\end{array}$ & $\begin{array}{c}\text { Number of } \\
\text { BRCA1 mutation }\end{array}$ & $\begin{array}{c}\text { Frequency of } \\
\text { mutation \% }\end{array}$ \\
\hline HBOC & 11 & 6 & 55 \\
HBOC susp. & 6 & 2 & 33 \\
HOC & 22 & 6 & 27 \\
HOC susp. & 22 & 5 & 23 \\
Others & 458 & 38 & 8,3 \\
Total & 517 & 57 & 11
\end{tabular}

For abbreviations see Table 1.

which 24 mutations were detected in 4153delA and $33 \mathrm{mu}-$ tations in 5382 insC and none in 300T/G. Division of mutations in the breast and ovarian cancer clinical groups are reflected in Tables 2 and 3.

The average age of patients at the time of diagnosis of breast cancer with BRCAl mutation was 49.2 years. From 65 patients with the BRCA1 mutation, in 34 cases the age of diagnosis of breast cancer was under 50 years, and in 31 cases, over 50 years.

Twenty-nine DNA samples for complete BRCA1/BRCA2 analysis were obtained from patients with hereditary breast and/or ovarian cancer but missing BRCAl founder mutations. Deleterious mutations were found in two families: splicing mutation (IVS15+1G > A) in the BRCA1 and frameshift mutation (886delGT) in the $B R C A 2$, respectively. Both mutations have already been reported in women with breast, or ovarian cancer (Frank et al., 1998; Adem et al., 2003). The family with a splicing mutation (IVS15+ $1 \mathrm{G}>\mathrm{A}$ ) in the BRCAl clinically fulfilled HBOC criteria. The proband carrying the splicing mutation was a woman who had been affected with breast cancer at the age of 35; her mother was diagnosed and ovarian cancer at the age of 58 and died at the age of 59, the proband's sister was diagnosed with breast cancer at the age of 44 and died at the age of 45 . The other family, who had a frameshift mutation (886delGT) in the BRCA2, fulfilled the criteria of hereditary breast cancer. There were four women affected with breast cancer in the family and one person affected with stomach cancer. The patient with the detected frameshift mutation was diagnosed with breast cancer at the age of 57 . Her sister was diagnosed for breast cancer at the age of 30 , the proband father was affected with stomach cancer at the age of 56 and died at the age of 62, his two sisters were affected with breast cancer and died at the age of 60 .

In addition to the abovementioned pathogenic mutations, 14 different polymorphisms were identified in the BRCA1/2 genes. Another three mutations in the BRCA2 gene with potential clinical interest were missense mutations T1915M, S1252F and T3306P. The first has already been reported in the BIC database and its clinical significance is unclear. The $\mathrm{T}$ allele $(5792 \mathrm{C}>\mathrm{T}$, rs4987117) is rather rare in various populations (NCBI SNP). The role of the T3306P mutation in disease development cannot be excluded definitely but it should be stressed that the carrier of this mutation harbours also a deleterious $886 \mathrm{delGT}$ mutation. The remaining $\mathrm{S} 1252 \mathrm{~F}$ mutation is also unclear as yet and requires further study to evaluate whether it has any impact on the development of cancer.

Colorectal cancer. Thirty-five patients of 1,053 fulfilled the diagnostic criteria of HNPCC. Eight patients matched HNPCC and 28 - suspected criteria of HNPCC. In 19 cases $M L H 1$ and $M S H 2$ testing was performed. In one case a mutation in $h M L H 1$ exon 19 with unknown clinical significance was detected. Two patients of 2,552 from the CRC Hereditary Cancer Institute database fulfilled the clinical criteria for FAP. Thus, the frequency of FAP is $0.08 \%$ $(2 / 2,552)$ of all CRC cases. Additionally, four polyposis patients were referred from the endoscopic department. Two of them had more than 100 polyps and consequently matched FAP diagnostic criteria. In the other two cases more than 50 polyps were detected and these cases were classified as unknown polyposis. Altogether four FAP cases and three their family members with clinical signs of FAP were identified and included in the study group. Four different germline mutations were detected in five polyposis cases examined for APC mutations. Two of the mutations (c.3942delG; p.Arg1314SerfsX7 and c.3286C > T; p.Gln1096X) are novel. The other two mutations in exon 11 c. $1438 \mathrm{C}>\mathrm{T}$; p.Gln480X and exon 15 c.2510C > G; p.Ser837X were reported in other populations.

In a group of colorectal cancer cases and controls moderate penetrance gene mutation testing was performed. The NOD2 3020insC mutation was tested in 362 colorectal cancer cases and in 758 controls. Mutations were detected in $28 / 362(7.7 \%)$ cases in the CRC group and in 61/758 (8\%) cases for the controls (no statistically significant difference between groups). The mutation CHEK2 I157T was found in 6/79 CRC (7.6\%); and controls 27/345 (7.8\%) (no significant difference between groups); the p16 mutation was tested in $362 \mathrm{CRC}$ cases and in 553 controls. Mutations were detected in 13/362 (3.6\%) CRC cases and in 11/553 $(2 \%)$ controls.

Endometrial cancer. Of 672 endometrial cancer patients, in $268(40 \%)$ showed no malignancies in their families. In 404 of the $672(60 \%)$ cases there was at least one malig- 
nancy among blood relatives. The following hereditary and familial cancer syndromes were observed: 6/672 (0.9\%) cases - site-specific HEC; $15 / 672(2.8 \%)$ cases - suspicion of site specific HEC; 4/672 (0.6\%) cases - FEC; 46/672 (6.8\%) cases — suspicion of FEC; 3/672 (0.4\%) cases HNPCC; 8/672 (1.2\%) cases - suspicion of HNPCC; $6 / 672(0.9 \%)$ cases - late onset HNPCC.

The probands were affected with endometrial cancer in HEC and HEC susp. families at the average age of 64 years (range 39 to 82 years), and in FEC and FEC susp. families at the average age of 61 at the time of diagnosis (range 38 to 78 years).

Carcinoma of the stomach, the most common associated malignancy, was found in 111 family members $(27.5 \%$ of all blood relatives). Lung cancer was diagnosed in 80 family members ( $19.8 \%$ of all blood relatives). Colorectal cancer was diagnosed in 64 (16.8\% of all blood relatives) family members. The average age of first-degree and seconddegree relatives at the onset of stomach cancer was 59 years and 61 years. The average age at the onset of lung cancer was 60 years, of endometrial cancer also 60 years. Mutation detection in the $M L H 1$ and $M S H 2$ genes was performed as described above (CRC chapter).

Prostate cancer. Of 676 prostate cancer family histories, 347 (51.3\%, 95\% CI: 47.6-55.1) had a positive cancer history and 329 (48.7\%, 95\% CI: 44.9-52.4) had a negative cancer history. Nine $(1.3 \%, 95 \%$ CI: $0.7-2.5)$ families matched definitive clinical diagnostic criteria of hereditary prostate cancer, 99 (14.6\%, 95\% CI: 12.2-17.5) families matched the suspected clinical diagnostic criteria of hereditary prostate cancer. In $82(12.1 \%, 95 \%$ CI: 9.9-14.8) cases besides prostate cancer at least two other malignant tumours were found among blood relatives (CFA, Cancer Familial Aggregation). The NBS1 gene 657del5 mutation was detected in $1(0.4 \%, 95 \% \mathrm{CI}: 0.1-2.0)$ case in the prostate cancer group and in $1(0.6 \%, 95 \%$ CI: $0.1-3.2)$ case in the control group. We also detected one $(1.7 \%, 95 \%$ CI: $0.3-9.0)$ case of the BRCAl gene ex20 (5382insC) mutation of 59 cases analysed in the prostate cancer group. No other $B R C A 1$ gene mutations were detected.

Pancreatic cancer. Inherited pancreatic cancer (PC) was found in four patients with PC in family history. Three of them reported one PC case in a family member, one of the patients reported two PC cases in the family. Incidence of inherited pancreatic cancer was $3.5 \%$ of 114 patients included in the study. The BRCA2 gene sequencing for pathogenic mutations in one female patient was conducted in full extent, in the other three patients - partially (also in the $11^{\text {th }}$ exon or "hot region”), yet, no changes were found. BRCA1, CDKN2A, STK11 and ARLTS1 sequencing also showed no pathogenic mutations in these genes. Thus, we can conclude that, perhaps, these mutations are not the most common in cases of hereditary pancreatic cancer, but no definite conclusion can be made due to the small number of patients tested.
No deleterious mutations were detected in the $C D K N 2 A$ gene encoding $\mathrm{p} 16$, and in the alternative exon $1 \beta$ of the $C D K N 2 A$ gene encoding $\mathrm{p} 14^{\mathrm{ARF}}$. The missense mutation A148T in the CDKN2A gene was detected in two patients. Mutations in exon 3 of the STK11 gene have been reported to be associated with pancreatic cancer. However, only the prevalent intronic polymorphism, the IVS3+12G $>\mathrm{T}$, was detected in $16.6 \%$ of DNA samples.

The BRCAl gene was screened for the two prevalent mutations in the population of Latvia, 5382insC and 4154delA, and for two less prevalent mutations, $300 \mathrm{~T}>\mathrm{G}$ and $185 \mathrm{de}-$ $1 A G$. The frequency of the BRCAl gene mutation carriers among PC patient DNA samples screened was rather high (4 of $114 ; 3.5 \%$ ). We screened DNA samples from 640 control individuals for the two most prevalent mutations and found only one carrier of the 5382insC mutation (the difference was statistically significant: $P<0.05$ ). Taking into account the relatively high prevalence of the BRCAl gene mutations among the PC patients tested, we analysed the same DNA samples of patients and controls for mutations in the ARLTS1 gene. Our results do not indicate that two of nonsynonymous polymorphic variants detected, the C392T (Pro131Leu) and T442C (Cys148Arg), are associated with increased cancer risk in the patient groups tested. However, a possible protective role of the $\mathrm{T} 442 \mathrm{C}$ mutation regarding PC can be observed (OR $0.43,95 \%$ CI $0.26-0.70, P=$ 0.001). In spite of insignificant family cancer histories of our PC patients because of the consecutively collected study group, we detected four G446A (Trp149Stop) mutation carriers of $90 \mathrm{PC}$ patients tested. The difference in mutation frequencies between PC patients (4/90) and controls (3/256) do not reach statistical significance (OR 3.9, 95\% CI 0.86-17.87, $P>0.05$ ).

\section{DISCUSSION}

Breast and ovarian cancer. Overall, the clinical frequency of definitive hereditary breast-ovarian cancer in our study is only $65 / 1,243(2.6 \%)$, which is approximately three times lower, compared to results of studies from other populations (Pohlreich, 2005; Stacey et al., 2006). In a study by John et al. (2004) the clinical frequency of definitive hereditary breast-ovarian cancer in hospital-based breast cancer patients was 204/2,834 (7\%). The low proportion of clinically positive hereditary breast-ovarian cancer cases in our study may be due to the relatively small family size in Latvia, due to migration, mainly connected with the Second World War, deportations, poor social and economical status of Latvia over many decades, and a low birth rate. The frequency of clinically suspected hereditary breast-ovarian cancer was similar to that of other geographic areas (Oszurek et al., 2001; Gronwald et al., 2005). Overall, the frequency in breast cancer group of the three $B R C A 1$ founder mutations was $3.0 \%$, but in ovarian cancer group - $11 \%$, more than three times higher. These results confirm the frequency of BRCA1 founder mutations in the ovarian cancer group is considerably higher. These results also confirm the earlier data on the presence of a BRCAl founder effect in Latvia, 
shared with Poland, Lithuania, Belarus and, to a lesser extent, other East European populations (Oszurek et al., 2001; Gronwald et al., 2005; Gronwald et al., 2008). The most frequent mutations in the BRCAl gene are 4153delA and 5382 insC. Only one mutation was detected in 300T/G. In the breast cancer group the most common mutations were detected in ex20 (5382 insC) - 48 and only 16 mutations ex11,17 (4153delA). The high occurrence of mutation ex20 (5382 insC) is described also in other East European populations (Gorski et al., 2000; Tikhomirova et al., 2005). Similar results were found in the patient group with ovarian cancer. In 5382 insC 33 mutations were found and in 4153 delA -24 mutations. No mutation was detected in 300T/G. These results are the observations published by Tikhomirova et al. (2005) and Gronwald et al. (2008).

The most interesting finding was a considerably low rate of mutations in families which present a strong family history of breast cancer. In the hereditary breast cancer (HBC) group, from 17 families which had three or more breast cancer cases among first degree relatives we found only one mutation. Compared with other studies, the frequency of the $B R C A 1$ gene mutation in the clinical positive HBC group is much higher (Pohlreich et al., 2005). This underlines the possibility of BRCAI mutation in other exons, not only three founder mutations (300T/G, 4153delA, 5382 insC) or mutations in the BRCA2 gene. For these families it is important to perform a complete BRCA1 and BRCA2 gene testing. For a first time, a $B R C A 2$ gene mutation positive hereditary breast cancer family was reported in Latvia.

The BRCAl gene founder mutations were more prevalent in families with a positive history of ovarian cancer (HBOC, HBOCsusp2. and HOC). In the breast cancer patient group $B R C A 1$ founder mutations were detected in $40 \%$ and in the ovarian cancer group - in $55 \%$ of clinical positive HBOC cases. These data confirm other studies on higher prevalence of BRCAl gene mutation in families affected with ovarian cancer (Levy-Lahad, 1997; Santarosa et al., 1999; Martin et al., 2001; Pohlreich, 2005). Approximately half of all mutations were detected in patients without cancer inheritance in family. We can conclude that cost effective molecular testing should be offered to a wide range of breast and ovarian cancer patients irrespective of family cancer history.

Colorectal cancer. We described the first four APC mutation-positive FAP cases in Latvia. The present frequency of FAP is lower than that reported in Finland, Lithuania, and other neighbouring countries, but the numbers might increase if more detailed screening is used. Initial molecular examinations reveal a partially unique spectrum of the $A P C$ gene mutations. Two of the mutations, c.3942delG; p.Arg1314SerfsX7 and c.3286C > T; p.Gln1096X, are novel.

Mutation in gene p16 shows 2 times higher CRC incidence than in controls. A similar trend, although nonsignificant after the Bonferroni correction, was observed for colorectal cancer $(\mathrm{OR}, 1.5 ; P>0.05)$ in the Polish population for the
A148T variant. These results suggest that p16 mutation may be associated with colorectal cancer risk, but the results need to be confirmed for a larger number of cases (Ogura et al., 2001; Kilpivaara et al., 2003).

Endometrial cancer. Few studies investigating the heritability of endometrial adenocarcinoma (EC) have been reported. In 1966, Lynch et al. (1991) reported 154 probands with EC, where in 20/154 (13\%) cases first degree relatives also were affected with endometrial carcinoma. In a pedigree study of 51 patient with endometrial adenocarcinoma, Boltenberg et al. (1990) noted also affected first degree relatives in four cases (8\%). Applying similar criteria, Sandles et al. (1998) found that 6 of $64(9.4 \%)$ probands with endometrial adenocarcinoma showed also affected first degree relatives. Suomi et al. (1995) found no families with hereditary site specific EC. One reason for such results could be their age criteria, i.e. excluding patients older than 60. Families with features of site-specific HEC in older age groups have been reported (Boltenberg et al., 1990; Sandles et al., 1998; Ollikainen et al., 2005). Our data show hereditary or familial basis in $12.7 \%$ of endometrial cancers, which corresponds to that reported elsewhere. Our data show another genetic pattern — a hereditary site-specific endometrial cancer that is characterised by a predisposition to endometrial cancer alone and may also play a role in the development of hereditary endometrial cancer. Further molecular examinations are necessary to evaluate the contribution of mismatch repair gene mutations to site specific hereditary endometrial cancer. However, we also have shown the contribution of other hereditary and familial cancer syndromes to development of endometrial cancer.

Prostata cancer. Except for earlier age at diagnosis, no phenotypic features have been clearly associated with hereditary prostate cancer (Fromont et al., 2008). As the definition of hereditary prostate cancer is based on family data in our study, any missing information of family cancer history is critical. Therefore, any family with no other malignancies among relatives should be carefully evaluated and considered as incomplete because data could be missing due to loss of contact during war time, deportation and migration in the middle of $20^{\text {th }}$ century in Latvia.

To establish the influence of $B R C A 1,1,793$ men with prostate cancer in Poland and 4,570 controls were genotyped for founder mutations (C61G, 4153delA and 5382insC). The results showed $4153 \mathrm{del}$ A to be more common in prostate cancer cases $(0.22 \%)$ than in controls $(0.04 \%)$. Data suggest that the 5382insC mutation is unlikely to be pathogenic for prostate cancer in the Polish population as it was more frequently present in the control population as in prostate cancer group (Cybulski et al., 2008). Compared to our data, we detected only one case of the BRCA1 gene mutation ex 20 (5382insC) from 68 individuals analysed. This may be explained by the high proportion of the Slavic population in Latvia.

Our data failed to support the involvement of the NBSI gene among our prostate cancer cases, as no statistically sig- 
nificant difference between prostate cancer (1 per 280) and the control group (1 per 173) was detected in Latvia. This supports previous studies and confirms the geographical difference between populations.

Pancreatic cancer. Inherited PC was found in $3.5 \%$ of 114 patients included in the study. USA statistics demonstrates that pancreatic cancer is inherited in $5-10 \%$ cases. In Europe, in Germany inheritance is around 3.5\%, Italy $-7.1 \%$ of all PC cases (Csokay et al., 1999; Calin et al., 2005). In our study the BRCA2 gene sequencing for pathogenic mutations in one female patient was conducted to a full extent, in the other three patients - partially (also in the $11^{\text {th }}$ exon or „hot region"), yet, no changes were found. However, studies show that BRCA2 mutation is one of the most common inherited mutations, ranging from $0-20 \%$ (depending from studies) in families with a strong family history (Debniak et al., 2006). We noted a relatively high prevalence of the two founder BRCAl gene mutations in DNA samples from PC patients, confirming that the pancreas is an important site of possible cancer development in both women and men from BRCA1 mutation carrier families. Three of four BRCAI gene mutation carriers detected in our study were men and only one of the carriers (a man of 65) reported a family history corresponding to a family with hereditary breast cancer syndrome. Three other carriers did not report cancer cases in their families, regardless of the deleterious character of mutations. We suspect that the role of the BRCAl gene mutations in the development of cancer in other sites may be more significant than assumed on the basis of family history data reported by breast and/or ovarian cancer patients from our population (Hahn et al., 2003; Frank et al., 2006; Chiaro et al., 2005). The significance of the BRCAl mutation in pancreatic cancer development was shown in large multicentre cohort study in Great Britain as well (RR 2.26, $P<0.05)$ (Jemal et al., 2002).

No deleterious mutations were detected in the genes associated with hereditary cancer syndromes, such as FAMMM or Peutz-Jeghers syndrome. The $482 \mathrm{G}>$ A missense mutation (Ala148Thr) in the CDKN2A gene was detected in two of PC patients tested and may be considered, perhaps, as a possible genetic factor that may modify the risk of cancer if combined with other risk factors - genetic, epigenetic, habitual or environmental, and might therefore affect cancer susceptibility to some degree. Taking into account a very early onset of disease (37 years) in one of our PC patients carrying the $482 \mathrm{G}>\mathrm{A}$ transversion, as well as rather early diagnosis (57 years) in another patient, both carrying in addition the highly prevalent $500 \mathrm{C}>\mathrm{G}$ variant in the noncoding region of exon 3 of the $C D K N 2 A$ gene, it is likely that the role of this $C D K N 2 A$ gene mutation in the PC development needs to be assessed more carefully. It was suggested recently that the Ala148Thr variant may be associated with a multi-organ cancer risk in the Polish population (Masojc et al., 2006). The analysis of the ARLTS1 gene fragment, containing two nonsynonymous and one nonsense variant of the gene, resulted in detection of a significant number of mutant allele carriers. The 392C > T (Pro131Leu) and 446G
$>$ A (Trp149Stop) are relatively rare variants, however, the $442 \mathrm{C}>\mathrm{T}$ (Cys148Arg) is highly prevalent in all populations studied. No association with cancer risk has been noted in carriers of the 392T allele (Thompson and Easton, 2002; Sinicka et al., 2004). Our results do not support also the involvement of the $442 \mathrm{C}>\mathrm{T}$ variant in PC susceptibility in our patients, but we can notice a possible protective effect of this allele relative to PC. The frequency of the $442 \mathrm{C}>\mathrm{T}$ mutation is statistically significantly lower among PC patients $(45.6 \%)$ than in controls $(66.0 \%$; OR $=0.43$; $95 \% \mathrm{CI}=0.26-0.70 ; P<0.05)$ or breast $(70.0 \%)$ and gynecological cancer patients $(61 \%)$. Analysis of more PC patients would be useful to confirm this finding. We consider our results as not conclusive as well concerning the role of the Trp149Stop variant in cancer susceptibility. This mutation was considered not to be associated with sporadic cancer (Tikhomirova et al., 2005). Taking into account the rather high prevalence of the 149Stop allele among cancer patients (more than $4 \%$ ) in our study, we suggest that cancer risk associated with it should be examined more carefully in sporadic and familial cancer cases.

\section{ACKNOWLEDGEMENTS}

The work was supported by the National Research Programme in Medicine 2006-2009, project No. 4, "Study on clinical and molecular features of hereditary tumour to elaborate optimal prevention and early detection strategy", Institute of Human Genetics, University of Bonn, Germany and Estonian Biocentre, University of Tartu, Estonia.

\section{REFERENCES}

Anonīms (2007). Latvijas vēža reǵistrs [Cancer Registry of Latvia]. Riga, Latvia (in Latvian).

Anonymous (2002). Globocan 2002. International Agency for Research on Cancer. http://www-dep.iarc.fr/globocan/globocan.html

Aretz, S., Stienen, D., Friedrichs, N., Stemmler, S., Uhlhaas, S., Rahner, N., Friedl, W. (2007). Somatic APC mosaicism: A frequent cause of familial adenomatous polyposis (FAP). Hum. Mutat., 28(10), 985-992.

Bartch, D.K., Kress, R., Sina-Frey, M., Grutzman, R., Gerdes, B., Pilarsky, C., Heise, J.V., Schulte, K.M., Ghadimi, M.B., Horstmann, O., Schmidt, J., Eisold, S., Hahn, S.A., Schulmann, K., Bock, W., Gress, T.M., Zugel, N., Prenzel, K., Messmann, H., Enlicher, E., Schneider, M., Ziegler, M., Schmiegel, K., Rothmund, M., Rieder, H. (2004). Epidemiology. Prevalence of familial pancreatic cancer in Germany. Int. J. Cancer, 110(6), 902-906.

Bisgaard, M., Ripa, R., Bülow, S. (2004). Mutation analysis of the adenomatous polyposis coli $(A P C)$ gene in Danish patients with familial adenomatous polyposis (FAP). Human Mutation: Mutation in Brief, No. 705, http://www3.interscience.wiley.com/homepages/38515/pdf/mutation/ 705.pdf

Boltenberg, A., Furgyik, S., Kullander, S. (1990). Familial cancer agregation in cases of adenocarcinoma corporis uteri. Acta Obstet. Gynecol. Scand., 69, 249-258.

Bratt, O. (2000). Hereditary prostate cancer. BJU Int. 85(5), 588-98.

Bülow, S., Nielsen, T., Bülow, C., Bisgaard, M.L., Karlsen, L., Moesgaard, F. (1996).The incidence rate of familial adenomatous polyposis. Results from the Danish Polyposis Register. Int. J. Colorectal Dis., 11(2), 88-91. 
Calin, G.A., Trapasso, F., Shimizu, M., Dumitru, C.D., Godwin, A.K., Ferracin, M., Bernardi, G., Rattan, S., Alder, H., Mabuchi, H., Overgaard, J., Mauro, F.R., Neuberg, D., Bullrich, F., Negrini, M., Croce, C.M. (2005). Familial cancer associated with a polymorphism in ARLTS1. New Engl. J. Med., 352, 1667-1676.

Chapelle, A., de la (2004). Genetic predisposition to colorectal cancer. Nat. Rev. Cancer., 4(10), 769-780.

Chiaro, M., Presciuttini, S., Bertacca, L., Zerbi, A., Longoni, B.M., Cipollini, G., Caligo, M.A., Boggi, U., Civitelli, V., Falconi, M., Pederzoli, P., Di Carlo, V., Cavallini, G., Mosca, F. (2005). Cancer risk among relatives of probands with pancreatic ductal adenocarcinoma. Offic. J. Int. HepatoPancreatoBiliary Assoc., 7(1), 76.

Csokay, B., Tihomirova, L., Stengrevics, A., Sinicka, O., Olah, E. (1999). Strong founder effects in $B R C A 1$ mutation carrier breast cancer patients from Latvia. Hum. Mutat., 14, 92.

Cybulski, C., Górski, B., Debniak, T., Gliniewicz, B., Mierzejewski, M., Masojc, B., Jakubowska, A., Matyjasik, J., Zlowocka, E., Sikorski, A., Narod, S.A., Lubinski, J. (2004). NBS1 is a prostate cancer susceptibility gene. Cancer Res., 64(4), 1215-1219.

Cybulski, C., Huzarski, T., Górski, B., Masojc, B., Mierzejewski, M., Debniak, T., Gliniewicz, B., Matyjasik, J., Zlowocka, E., Kurzawski, G., Sikorski, A., Posmyk, M., Szwiec, M., Czajka, R., Narod, S.A., Lubinski, J. (2004). A novel founder CHEK2 mutation is associated with increased prostate cancer risk. Cancer Res., 64(8), 2677-2679.

Cybulski, C., Górski, B., Gronwald, J., Huzarski, T., Byrski, T., Debniak, T., Jakubowska, A., Wokołorczyk, D., Gliniewicz, B., Sikorski, A., Stawicka, M., Godlewski, D., Kwias, Z., Antczak, A., Borkowski, T., Szwiec, M., Posmyk, M., Narod, S.A., Lubiński, J. (2008). BRCA1 mutations and prostate cancer in Poland. Eur. J. Cancer Prev., 17, 62-66.

Debniak, T., Scott, R.J., Huzarski, T., Byrski, T., Rozmiarek, A., Debniak, B., Gorski, B., Cybulski, C., Medrek, K., Masojc, B., Lener, M., Jaworowska, E., Oszutowska, D., Szymanska, A., Castaneda, J., Wetering, T., Suchy, J., Kurzawski, G., Oszurek, O., Narod, S., Lubinski, J. (2006). CDKN2A common variant and multi-organ cancer risk - a population-based study. Int. J. Cancer, 118(12), 3180-3182.

Dębniak, T., Cybulski, C., Kurzawski, G., Górski, B., Huzarski, T. (2006). Low-risk genes and multi-organ cancer risk in the Polish population. Hered. Cancer Clin. Pract., 4(1), 52-55.

Ford, D., Easton, D.F., Stratton, M., Narod, S., Goldgar, D.(1998). Genetic heterogeneity and penetrance analysis of the BRCA1 and BRCA2 genes in breast cancer families. The Breast Cancer Linkage Consortium. Amer. J. Hum. Genet., 62(3), 676-689.

Frank, B., Hemminki, K., Meindl, A., Wappenschmidt, B., Klaes, R., Schmutzler, R., Untch, M., Bugert, P., Bartram, C.R., Burwinkel, B. (2006). Association of the ARLTS1 Cys148Arg variant with familial breast cancer risk. Int. J. Cancer, 118, 2505-2508.

Fromont, G., Yacoub, M., Valeri, A., Mangin, P., Vallancien, G., Cancel-Tassin, G., Cussenot, O. (2008). Differential expression of genes related to androgen and estrogen metabolism in hereditary versus sporadic prostate cancer. Cancer Epidemiol Biomarkers Prev., 17, 1505-1509.

Górski,B., Byrski,T., Huzarski,T. (2000). Founder mutations in the BRCA1 gene in Polish families with breast-ovarian cancer. Amer. J. Hum. Genet., 66, 1963-1968.

Gronwald, J., Huzarski, T., Oszurek, O., Janicka, A., Szymańska-Pasternak, J., Górski, B., Menkiszak, J., Rzepka-Górska, I., Lubiński, J. (2008). Hereditary breast and ovarian cancer. Hered. Cancer Clin. Pract., 6(2), 88-98.

Gronwald, J., Elsakob, P., Gorski, B., Lubinski, J. (2005). High incidence of 4153delA BRCA1 gene mutations in Lithuanian breast- and breast-ovarian cancer families. Breast Cancer Res. Treat., 94(2), 111-113.

Hahn, S.A., Greenhalf, B., Ellis, I., Sine-frey, M., Rieder, H., Korte, B., Gerdes, B., Kress, R., Ziegler, A., Campra, D., Grutzmann, R., Rehder, H., Rothmund, M., Schmiegel, W., Neoptolemos, J.P., Bartsch, D.K. (2003).
BRCA2 germline mutations in familial pancreatic carcinoma. J. Natl. Cancer Ins., 95, 214-221.

Hughes, C., Murphy, A., Martin, C., Sheils, O., O’Leary, J. (2005). Molecular pathology of prostate cancer. J. Clin. Pathol., 58, 673-684.

Jarvinen, H.J. (1992). Epidemiology of familial adenomatous polyposis in Finland: Impact of family screening on the colorectal cancer rate and survival. Gut, 33(3), 357-360.

Jacobi, C.E., Jonker, M.A., Nagelkerke, N., van Houwelingen, J., Bock, G.H. (2003). Prevalence of family histories of breast cancer in the general population and the incidence of related seeking of health care. J. Med. Genet., 40(7), e83.

Jemal, A., Thomas, A., Murray, T., Thun, M. (2002). Cancer statistics. Ca. Cancer J. Clin., 52, 23-47.

John, E.M. (2004). The Breast Cancer Family Registry: An infrastructure for cooperative multinational, interdisciplinary and translational studies of the genetic epidemiology of breast cancer. Breast Cancer Res., 6(4), R375-389.

Kilpivaara,O., Laiho,L., Aaltonen, A., Nevanlinna, H. (2003). CHEK2 1100delC and colorectal cancer. J. Med. Genet., 40(10), 110.

Kurzawski, G., Suchy, J., Kladny, J., Grabowska, E., Jakubowska, A., Debniak, T., Cybulski, C., Kowalska, E., Szych, Z., Domagala, W., Scott, R.J., Lubinski, J. (2004). The NOD2 3020insC mutation and the risk of colorectal cancer. Cancer Res. 64(5), 1604-1606.

Levy-Lahad, E. (1997). Founder BRCA1 and BRCA2 mutations in Ashkenazi Jews in Israel: Frequency and differential penetrance in ovarian cancer and in breast-ovarian cancer families. Amer. J. Hum. Genet., 60(5),1059-1067.

Lichtenstein, P., Holm, N.V.,Verkasalo, P.K.,Iliadou, A., Kaprio, J., Koskenvuo M., Pukkala E., Hemminki, K. (2000). Environmental and heritable factors in the causation of cancer - analyses of cohorts of twins from Sweden, Denmark, and Finland. New Engl. J. Med., 343, 78-85.

Lynch, H.T., Lanspa, S., Smyrk, B.B., Watson, P., Lynch, J. (1991). Hereditary non-polyposis colorectal cancer (Lynch syndromes I and II) genetics, pathology, natural history and cancer control, Part I. Cancer Genet. Cytogenetic., 53, 143-160.

Martin, A.M., Blackwood, M.A., Antin-Ozerkis, D., Shih, H.A., Calzone, K., Colligon, T., Seal, S., Collins, N., Stratton, M.R., Weber, B.L., Nathanson, K.L. (2001). Germline mutations in BRCA1 and BRCA2 in breast-ovarian families from a breast cancer risk evaluation clinic. J. Clin. Oncol., 19(8), 2247-2253.

Masojc, B., Mierzejewski, M., Cybulski, C., Wetering, T., Debniak, T., Gorski, B., Jaworowska, E., Tarnowska, C., Lenner, M., Scott, R.J., Lubinski, J. (2006). Cancer Familial Aggregation (CFA) and G446A polymorphism in ARLTS1 gene. Breast Cancer Res. Treat., 99(1), 59-62.

Mecklin,J.-P., Jarvinen, H.I. (1991). Tumor spectrum in cancer-family syndroma. Cancer, 68, 1109-1112.

Ogura, Y., Bonen, D.K., Inohara, N., Nicolae, D.L., Chen, F.F., Ramos, R., Britton, H., Moran, T., Duerr, R., Achkar, R., Brant, S., Bayless, T., Kirschner, B., Hanauer, S., Nunez, G., Cho, J.H. (2001). A frameshift mutation in NOD2 associated with susceptibility to Crohn's disease. Nature, 411(6837), 603-606.

Oszurek, O., Gorski, B., Gronwald, J., Prosolow, Z., Uglanica, K., Murinow, A., Bobko, I., Norik, D., Byrski, T., Jakubowska, A., Lubinski, J. (2001). Founder mutations in the BRCA1 gene in west Belarusian breast-ovarian cancer families. Clin. Genet., 60(6), 470-471.

Ollikainen, M., Abdel-Rahman, W., Moisio, A., Lindroos, A., Kariola, R., Jarvela, I., Poyhonen, M., Butzow, R., Peltomaki, P. ( 2005). Molecular analysis of familial endometrial carcinoma: A manifestation of hereditary nonpolyposis colorectal cancer or a separate syndrome. J. Clin. Oncol., 23(21), 4609-4616.

Pohlreich, P. (2005). High proportion of recurrent germline mutations in the $B R C A 1$ gene in breast and ovarian cancer patients from the Prague area. Breast Cancer Res., 7(5), R728-736. 
Rennert, H., Zeigler-Johnson, C., Addya, K., Finley, M., Walker, A., Spangler, E., Leonard, D., Wein, A., Malkowicz, S., Rebbeck, T. (2005). Association of susceptibility alleles in ELAC2/HPC2, RNASEL/HPC1, and MSR1 with prostate cancer severity in European American and African American men. Cancer Epidemiol. Biomarkers Prev., 14(4), 949-957.

Sandles, L.G. (1998). Familial endometrial adenocarcinoma. Clin. Obstet. Gynecol., 41,167-171.

Santarosa, M., Liede, A., Aube, J., Finch, A., Kwan, E., Jack, E., Narod, S., Randall, S., Hugel, L., Clark, K. (1999). BRCA1 and BRCA2 genes: Role in hereditary breast and ovarian cancer in Italy. Int. J. Cancer, 83(1), 5-9.

Sinicka, O., Stengrevics, A., Eglitis, J., Smite, D., Shomshteine, Z., Tihomirova, L. (2004). Ovarian cancer in Latvia is attributable to recurrent mutations in the BRCA1 gene. Acta Universitatis Latviensis. Biology, 676, 17-25.
Suomi, R., Hakala,T., Pietila, A., Laminen, A., Mecklin, J.-P., Lehtovirta, P. (1995). Hereditary aspects of endometrial adenocarcinoma. J. Cancer, 62,132-137.

Stacey, S.N., Sulem, P., Johannsson, O., Helgason, A., Gudmundsson, J., Kostic, J., Kristjansson,K., Sveinsson,T., Myrdal,G., Grimsson,H., Kong,A., Stefansson,K. (2006). The BARD1 Cys557Ser variant and breast cancer risk in Iceland. PLoS Med., 3(7), e217.

Thompson, D., Easton, D.F. (2002). Cancer incidence in BRCA1 mutation carriers. J. Natl. Cancer Inst., 94(18), 1358-1365.

Tikhomirova, L., Sinicka, O., Smite, D., Hodgson, S.V., Stengrevics, A. (2005). High prevalence of two BRCA1 mutations, 4154delA and 5382ins in Latvia. Fam. Cancer, 4, 77-84.

Vasen, H.F. (2001). Erfelijke tumoren. Richtlijnen voor diagnostiek en preventie. Stichting Opsporing Erfelijke Tumoren \& Vereniging klinische Genetica Nederland Werkgroep Klinische Oncogenetica. 21.

Received 11 July 2009

\section{IZPLATİTĀKĀ PĀRMANTOTĀ VĒŽA GADĪJUMU EPIDEMIOLOG̣ISKO, KLĪNISKO UN MOLEKULĀRO İPATNĪBU AGRĪNAS NOTEIKŠANAS STRATĒG̣IJA}

Darba mērkis bija izpētīt pārmantotā krūts, olnīcu, kolorektālā, endometrija, prostatas un aizkunğa dziedzera vēža epidemioloǵiskās, klīniskās un molekulārās īpatnības Latvijā. Pētījums tika veikts no 2006. gada līdz 2009. gadam. Kopumā gímenes onkoloğiskā anamnēze un perifēro asinu DNS paraugi tika iegūti 5040 vēža gadījumos. Tika veikti vairāk kā 6000 molekulārie testi, lietojot polimerāzes k,ēdes reakcijas, sekvenēšanas, denaturējošo augstas veiktspējas škiidrās hromatogrāfijas metodes un citus molekulāros izmeklējumus. Pirmo reizi Latvijā atklāta $B R C A 2$ gēna mutācija, kas pārmantota krūts vēža gadījumā. Ar lielu gadījumu skaitu tika apstiprināts divu Latvijā biežāko BRCAl gēna mutāciju (4153delA and 5382insC) testa lietderīgums visiem krūts un olnīcu vēža gadījumiem, neatkarīgi no ǵimenes onkoloǵiskās anamnēzes. Pārmantotā olnīcu vēža pētījumā tika konstatēts, ka katrs devītais olnīcu vēža gadījums Latvijā ir saistīts ar BRCAl gēna mutāciju. Pirmo reizi arī ziņojam par ǵimenes adenomatozās polipozes gadījumiem, kas saistīi ar APC gēna mutācijām. Pētìjuma gaitā iegūti unikāli epidemioloğiski dati par pārmantoto endometrija un prostatas vēzi, kā arī atklāts, ka 3,5\% gadījumos aizkun,ǵa dziedzera vēzis saistīts ar patogēnu mutāciju BRCAl gēnā. 